\title{
Til umhugsunar eftir dóm Breiviks
}

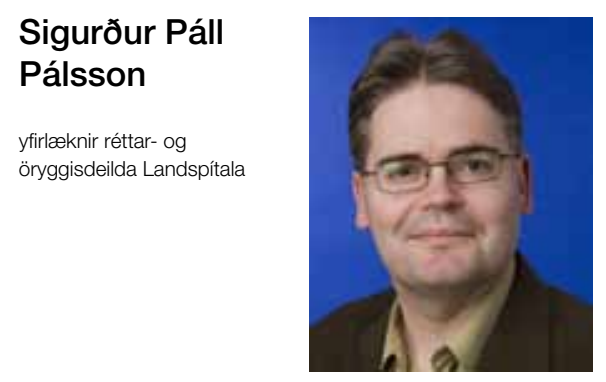

sigpp@landspitali.is

Í fyrra framdi karlmaður fjöldamorð í Noregi. Eftir atburðinn hófst fjölmiðlaumræða um geðhag mannsins. Noregur er frændpjóð okkar, manndráp eru par sjaldgæf, eða 1,6/100.000 á ári (meðaltal áranna 20002009). Раð er svipað og hér á sama tímabili (0,8/100.000/ár). Nýgengi sjálfsvíga er einnig sambærilegt, nú 11/100.000 á ári í Noregi (2000-2009) en 11,8 á sömu mælistiku á Íslandi á sama tímabili. Fjöldi rúma á réttargeðdeildum og almennum geðdeildum er helmingi meiri par en hér.

Í Noregi er læknisfræðilegt mat lagt til grundvallar ákvörðun dómstóla um sakhæfi. Hugtakið sturlun (psykose) hefur lykilpýðingu í norsku hegningarlögunum, pví sturluðum manni skal ekki refsað. Sé niðurstaða sérfræðinga sú að ákærði sé haldinn geðveiki eða alvarlegum andlegum annmarka er hefð fyrir pví að dómstólar byggi á pví áliti. Hvorki sérfræðingar né dómstólar hafa purft að huga аð orsakatengslum geðsjúkdóms og verknaðar. ${ }^{1-3}$ Dómurinn purfti að meta hvort Breivik væri sturlaður (psykotisk) eða ekki. Í málinu voru tvö andstæð sérfræðiálit. Annað sagði hann með aðsóknargeðklofa og sturlaðan, en hitt taldi hann persónuleikaraskaðan en ekki sturlaðan. Í dómnum er ítarlega fjallað um skilgreiningar á geðklofa og dregið í efa að Breivik uppfylli öll skilmerki aðsóknargeðklofa.

Dómurinn skoðaði muninn á ýktum hugmyndum, öfgahugmyndum, til dæmis trúarlegum og pólitískum, og hreinum ranghugmyndum. Einnig mat hann hvenær práhyggja, fantasíur og forboðnar hugmyndir eru skiljanlegar og partur af sálarlífi persónuleika veiklaðs manns, og hvenær mörkum ranghugmyndar er nád. Dómstóllinn sá hvorki merki um ofskynjanir eða hugsanat- ruflun né um svokölluð neikvæð einkenni geðklofa hjá Breivik. Dómurinn benti á að Breivik hefði notað hið örvandi efnið efedrín og stera fyrir morðin.

Hvernig hefði verið tekið á Breivik-málinu fyrir íslenskum dómstólum? Nýlegur dómur sýnir mun á íslensku sakamálaréttarfari og norsku. Hæstiréttur sneri við niðurstöðu héraðsdóms um ósakhæfi og vék til hliðar mati tveggja dómkvaddra sérfræðinga sem töldu sakborning geðveikan og ósakhæfan. Mat peirra var ekki samhljóða vegna mismunandi geðgreininga. Í dómi Hæstaréttar (198/2011) segir:

„Með pessu ákvæði [15. gr. almennra hegningarlaga] eru sett ströng skilyrði fyrir sakhæfisskorti í íslenskum rétti, par á meðal verður andlegur annmarki, svo sem geðveiki, að vera á háu stigi til pess að hann leiði til refsileysis af peim sökum. Рað nægir pó ekki til skorts á sakhæfi, heldur verður maður að hafa verið alls ófær um að stjórna gerðum sínum vegna hins andlega annmarka pegar hann framdi verknað sem lýstur er refsiverður að lögum. [...] Samkvæmt pví leiðir pað ekki til sakhæfisskorts pótt sá, sem uppvís hefur orðið að refsiverðum verknaði, hafi brenglað raunveruleikaskyn eða sé haldinn ranghugmyndum af völdum geðsjúkdóms nema hann hafi alls ekki verið fær um að hafa stjórn á gerðum sínum pegar hann vann verkið."

Hæstiréttur notar lögfræðilegan mælikvarða, mat sjálfur málsatvik og taldi einstaklinginn hafa vitað og skilið hvað hann var að gera. Andi M`Naghten-reglna skín hér í gegn. ${ }^{2}$

Dómstólar Norðurlanda virðast meta mál á mismunandi hátt pótt hegningarlagaákvæðin um ósakhæfi séu svipuð eða sambærileg. Spyrja má hvort Breivik væri á réttargeðdeild hefði hann myrt einn mann? Breytti fjölmiðlaumræðan gangi málsins? Greining geðrofs getur verið mjög flókin á persónuleikaröskuðum einstaklingum. Oftast tryggir langur skoðunartími, ítarlegt mat í innlögn, best gæði slíkrar greiningar í vafatilvikum. Mikilvægt er einnig að nota hlutlæga skala við mat eftir pví sem hægt er. Рað kann að hafa haft áhrif á fyrra matið á Breivik að pá var hann hugsanlega enn að jafna sig eftir verkun steranna. Sterar geta valdið tímabundinni sturlun sem stundum stendur í margar vikur. Í máli Breivik krafðist ákæruvaldið ósakhæfis og vistunar á réttargeðdeild. Hvers vegna? Litlar líkur eru á pví að persónuleiki Breiviks breytist. Vildi ákæruvaldið tryggja ævilanga vistun á réttargeðdeild? Pessi grunsemd leiðir til ópægilegra vangaveltna um tilgang réttargeðdeilda. Fyrir geðlæknum er tilgangurinn meðferð og endurhæfing með tilheyrandi öryggi. Alpjóðageðlæknasamtökin (WPA) ályktuðu strax árið 1977 (Hawaii-yfirlýsingin) að geðlæknar mættu ekki taka pátt í pvingandi meðferð á einstaklingum sem ekki eru geðveikir. Menn verða að skilja að persónuleikaraskaðir einstaklingar eru yfirleitt hættulegastir og meðferðarsvörun peirra oft lítil. Fæstir peirra vilja meðferð eða vinna að pví að breyta persónuleika sínum. Pessu er öfugt farið með geðklofasjúkdóm og geðhvörf par sem góð og árangursrík meðferð er til í flestum tilvikum. Geðklofasjúklingar sýna heldur meiri tilhneigingu til ofbeldisverka en almenningur, en pað er oftast tengt meðferðarleysi og notkun fíkniefna. ${ }^{4}$ Peir eru hins vegar hundraðfalt líklegri til að taka eigið líf en að fremja morð. Alvarlega geðsjúkir eru einnig í aukinni áhættu á að verða fyrir aðkasti, slysum og ofbeldi, og eru til dæmis sjöfalt líklegri til að vera myrtir en aðrir. ${ }^{5}$

\section{Heimildir}

1. Grøndahl P. Scandinavian forensic psychiatric practicesan overview and evaluation. Nord J Psychiatry 2005; 59: 92-102.

2. Pórmundsson J. Afbrot og refsiábyrgð III. Háskólaútgáfan, Reykjavík 2004: 84-115.

3. Psykisk störning, brott och ansvar. Betänkande från Psykansvarskommittén. regeringen.se/sb/d/108/a/488

4. Fazel S, Långström N, Hjern A, Grann M, Lichtenstein P. Schizophrenia, substance abuse, and violent crime. JAMA. 2009; 301: 2016-23.

5. Hiroeh U, Appleby L, Mortensen PB, Dunn G. Death by homicide, suicide, and other unnatural causes in people with mental illness: a population-based study. Lancet 2001; 358: 2110-2

Reflection on the Breivik verdict Sigurður Páll Pálsson MD, PhD, Chief Psychiatrist, Forensic psychiatry and security units Landspítali University Hospital, Reykjavík. 